\title{
Cywilizacyjno-kulturowy kontekst „pomarańczowej rewolucji” na Ukrainie
}

$\mathrm{O}$ statnie miesiące 2004 r. były na Ukrainie okresem ważkich wydarzeń politycznych, rozgrywających się wokół wyborów prezydenckich, a mających znaczenie dla przyszłości społeczeństwa ukraińskiego. $\mathrm{Na}$ wydarzeniach tych skupiło się zainteresowanie mediów światowych; odżyły wokół nich dyskusje akademickie na temat cywilizacyjnej tożsamości Ukrainy oraz wyznaczenia jej miejsca i roli w różnych inicjatywach integracyjnych na Starym Kontynencie i obszarze postradzieckim. Najistotniejszym z nich, z punktu widzenia geopolitycznego, była tzw. ,pomarańczowa rewolucja”. Zwolennicy kandydata opozycji w wyborach prezydenckich, Wiktora Juszczenki, byłego premiera i byłego szefa ukraińskiego banku narodowego, w odpowiedzi na nadużycia i fałszerstwa wyborcze, których dopuściły się ówczesne władze, zorganizowali masowy protest, obejmujący zwłaszcza zachodnią i centralną Ukrainę. „,Rewolucja” ta miała bezkrwawy, pokojowy przebieg; ograniczała się do nieustannych manifestacji, okupacji budynków administracji centralnej oraz wystąpień i happeningów. Centralnym jej miejscem stał się Plac Niepodległości w Kijowie, tzw. „Majdan”, na którym przez kilka tygodni, nieprzerwanie odbywał się wiec poparcia dla kandydata opozycji. Określenie „pomarańczowa” wzięło się od barw wyborczych W. Juszczenki. „Pomarańczowa rewolucja" nie była wszakże tylko wydarzeniem, które zmieniło sytuację polityczną na Ukrainie (odsunięcie od władzy ekipy byłego prezydenta Leonida Kuczmy i kontrkandydata Juszczenki w „wyścigu” o fotel prezydenta byłego premiera Wiktora Janukowycza oraz powrót do pryncypiów demokratycznych w stosunkach wewnątrzpaństwowych), jej konsekwencje mają o wiele szerszy, międzynarodowy i cywilizacyjny zasięg.

Artykuł niniejszy jest próbą interpretacji cywilizacyjnej „pomarańczowej rewolucji” i jej skutków dla społeczeństwa ukraińskiego oraz systemu międzynarodowego, a zwłaszcza porządku europejskiego. 


\section{Tożsamość cywilizacyjna Ukrainy}

Współczesne niepodległe państwo ukraińskie powstało 24 sierpnia 1991 r. w wyniku zakończenia procesu rozpadu Związku Socjalistycznych Republik Radzieckich (ZSRR). W ramach Związku Radzieckiego Ukraina funkcjonowała jako formalnie suwerenna Ukraińska SRR (proklamowana 6 stycznia 1919 r.), będąca nawet członkiem Organizacji Narodów Zjednoczonych (ONZ); faktycznie jednak ZSRR było państwem silnie scentralizowanym, a poszczególne republiki w pełni zależne od władz na Kremlu, stąd też takie quasi-państwo nie sprostało aspiracjom ludności ukraińskiej, a w szczególności tej jej części, którą wyróżniało silne poczucie świadomości i odrębności narodowej. Republika Ukrainy nawiązuje do długowiekowej tradycji państwowej Rusi Kijowskiej (przyjęcie chrztu w 988 r.) oraz krótkotrwałych struktur ukraińskiego państwa narodowego (1917-1921), jakimi były Ukraińska Republika Ludowa (proklamowana 20 listopada 1917 r.) i Zachodnio-Ukraińska Republika Ludowa (proklamowana 13 listopada $1918 \mathrm{r}$ ), zjednoczone 22 stycznia $1919 \mathrm{r}{ }^{1}$

W okresie między upadkiem Rusi Kijowskiej (1240 r.) a utworzeniem ukraińskich republik narodowych na początku XX w. Ukraińcy nie posiadali własnego państwa. Ich ziemie znajdowały się pod panowaniem Złotej Ordy, Wielkiego Księstwa Litewskiego, Królestwa Polskiego i Rzeczypospolitej Obojga Narodów, Imperium Rosyjskiego oraz monarchii Habsburgów (Galicja Wschodnia, Ruś Zakarpacka i Bukowina). W latach 1921-1939 zachodnia część Ukrainy wchodziła w skład odrodzonego państwa polskiego.

Zawiłe losy społeczeństwa ukraińskiego sprawiają, że w budowaniu jego tożsamości kulturowej i cywilizacyjnej przeplatają się różne wzorce kulturowe i systemy wartości. Pierwotnym pokładem jest spuścizna pogańsko-słowiańska wraz z elementami germańsko-skandynawskimi oraz greckimi.

Od X w. za sprawą przyjęcia przez Ruś Kijowską chrztu w obrządku wschodnim, ziemie ukraińskie znajdują się pod wpływem chrześcijaństwa ortodoksyjnego i cywilizacji bizantyńskiej. Wpływy bizantyńskie w społeczeństwie ukraińskim, szczególnie w środkowej i wschodniej Ukrainie, ugruntowywało Imperium Rosyjskie i jego „mutacja”, jaką był ZSRR, do którego ziemie te należały przez około cztery stulecia.

1 A. Chojnowski, Ukraina, Warszawa 1997. 
Wraz z ekspansją militarną zachodniochrześcijańskich władców polskich i węgierskich na Wschód, na zachodnie rubieże Rusi (Ruś Halicko-Włodzimierska) oddziaływała kultura łacińska. Docierała też na dwory książąt ruskich, w tym do Kijowa, dzięki stosunkom dyplomatycznym, wojskowym układom sojuszniczym i wymianie handlowej ze średniowiecznymi państwami zachodnimi oraz dzięki małżeństwom, które zawierali władcy Rusi z księżniczkami, wywodzącymi się z rodów zachodnioeuropejskich. Proces latynizacji nasilił się w wyniku unii polsko-litewskich oraz po przyłączeniu niemal całej dzisiejszej Ukrainy do Korony Polskiej (1569 r.). Zwieńczeniem tego procesu była tzw. unia brzeska (1596 r.), na mocy której większość duchownych i wiernych cerkwi prawosławnej, działającej na obszarze Rzeczypospolitej, przyjęła zwierzchność papieża, przy zachowaniu obrządku wschodniego (powstała wówczas cerkiew grekokatolicka).

Od XIII aż do XVIII w. ziemie ukraińskie były terenem najazdów koczowniczych ludów mongolsko-tatarskich i oddziaływania, zwłaszcza w okresie panowania Złotej Ordy, ich cywilizacji, nazywanej przez niektórych badaczy dziejów turańską (F. Koneczny) ${ }^{2}$.

Procesy historyczne wpłynęły na skład etniczny dzisiejszej Ukrainy. Ludność zamieszkała na jej terenie jest zróżnicowana pod względem narodowościowym i językowym, aczkolwiek największą społecznością są Ukraińcy, którzy stanowią ok. 78\% ogółu obywateli państwa ukraińskiego. Wielu z nich jednak posługuje się językiem rosyjskim, traktując go jako język pierwszy (ojczysty), co jest z pewnością konsekwencją stuleci rusyfikacji, szczególnie na ziemiach środkowej, wschodniej i południowej Ukrainy, a także niekiedy wśród mieszkańców tej części republiki jest przejawem swego rodzaju snobizmu - język rosyjski kojarzony jest z kulturą miejską, a więc w ich mniemaniu wyższą, natomiast ukraiński z chłopską, czyli niską, ludową. Stąd też niektórzy, mimo że bardzo dobrze znają ukraiński, na co dzień używają zwykle języka rosyjskiego. Rosjanie na Ukrainie stanowią społeczność ok. siedemnastoprocentową. Zamieszkują głównie wschodnie i południowe regiony republiki, zwłaszcza obwody: ługański, doniecki, charkowski, dnietropietrowski i odeski oraz Krym. Jednak tylko na Krymie, który z Ukrainą związany jest stosunkowo od niedawna (do Ukraińskiej SRR został przyłączony w 1954 r.),

2 Zob. B. Grekow, Ruś Kijowska, Warszawa 1955; W. Serczyk, Historia Ukrainy, Wrocław-Warszawa-Kraków-Gdańsk 1979. 
Rosjanie przewyższają liczebnie Ukraińców i stanowią większość mieszkańców Półwyspu. Prócz Rosjan na Ukrainie zamieszkują także inne mniejszości narodowe, z których żadna nie wyróżnia się znacznym potencjałem demograficznym i nie przekracza $1 \%$ ogółu mieszkańców. Są to m.in.: Białorusini $(0,6 \%)$, Mołdawianie $(0,5 \%)$, Tatarzy krymscy $(0,5 \%)$, Bułgarzy $(0,4 \%)$ oraz Węgrzy, Rumunii, Polacy, Żydzi, Grecy, Tatarzy, Romowie, Ormianie, Niemcy, Gagauzi ${ }^{3}$.

Generalnie, na kształt oblicza kulturowego i cywilizacyjnego współczesnej Ukrainy największy wpływ wywierają elementy bizantyńsko-prawosławne, jak również europejskie (łacińskie). Dlatego można stwierdzić, że jej tożsamość wyznaczana jest przez oscylowanie między Wschodem, czyli cywilizacją bizantyńską, nazywaną też prawosławną, której głównym ośrodkiem od czasu upadku Konstantynopola jest Rosja (ściślej Moskwa jako „trzeci Rzym”) a Zachodem, tj. cywilizacją zachodnią (europejską, łacińską) ${ }^{4}$.

Uproszczeniem jest jednak teza, głoszona m.in. przez amerykańskiego politologa Samuela P. Huntingtona, w myśl której przez Ukrainę przebiega wyraźna granica między cywilizacją zachodnią a prawosławną. Zachodnia Ukraina, w której dominuje ludność wyznania unickiego (grekokatolicy) przynależy ipso facto do Zachodu, podczas gdy ukraińska społeczność prawosławna wyznacza przestrzeń dla cywilizacji prawosławnej. Rozważa się przy tym rozpad państwa ukraińskiego na dwie części ${ }^{5}$. Należy jednak mieć na uwadze, że cywilizacja jest systemem społecznym, w którym religia stanowi jeden z jego elementów, być może najistotniejszy, ale w każdym bądź razie nie jedyny; tworzą go też inne elementy, tj. polityka, ład międzynarodowy, kultura, gospodarka, nauka i technika ${ }^{6}$. Nie właściwe jest zatem zredukowanie cywilizacji do samej tylko religii, choć wiele z tzw. cywilizacji partykularnych określa się właśnie poprzez dominujące $\mathrm{w}$ danej społeczności wyznanie wiary, np. cywilizację żydowską, islamską, hinduską, buddyjską itd., co wszakże wcale nie ozna-

${ }^{3}$ P. Andrusieczko, Zmiany struktury narodowościowej i językowej na Ukrainie w kontekście wyników spisu powszechnego z 2001 roku, „Sprawy Narodowościowe. Seria nowa" 2004, z. 24-25, s. 201.

4 A. Wilson, Ukraińcy, Warszawa 2002, s. 40-46.

5 S. P. Huntington, Zderzenie cywilizacji i nowy ksztalt ładu światowego, Warszawa 1997, s. 36. Ostatnio ukazał się jego esej Wielki uskok przed skokiem, w którym podtrzymuje wcześniej sformułowane tezy („,Forum” 2004, nr 51/52, s. 14-22).

6 A. Modrzejewski, Cywilizacja jako system społeczny, „Cywilizacja i Polityka” 2004, nr 2, s. 11-27. 
cza, że wyznawca jednej z wielu światowych religii jest automatycznie przyporządkowany do kręgu kulturowego, który z religii tej wyrasta. Za przykład posłużyć mogą tu zasymilowani w społeczeństwach zachodnich wyznawcy islamu czy judaizmu bądź też zwesternizowane społeczności Bliskiego i Dalekiego Wschodu (np. Libańczycy, Turcy, Japończycy, Koreańczycy z Południa czy Tajwańczycy).

Wybory prezydenckie z końca 2004 r. pokazały, że Huntingtonowski uproszczony model stosunków cywilizacyjnych na Ukrainie nie przystaje do rzeczywistości, chociaż stał się skutecznym narzędziem propagandowym w rękach obozu skupionego wokół kandydata prorosyjskiego, W. Janukowycza oraz sił politycznych z Federacji Rosyjskiej, grożących Zachodowi widmem rozpadu ukraińskiego państwa i destabilizacją w tym regionie Starego Kontynentu. Skutkiem owej działalności propagandowej było pojawienie się $\mathrm{w}$ zachodnich mediach, jak również w wypowiedziach zachodnich polityków prognoz, zakładających „,czarny scenariusz”, czyli demontaż Ukrainy. Np. prezydent Aleksander Kwaśniewski w dość umiarkowanym tonie stwierdził m.in., że ,wybory uzmysłowiły nam wyraźnie, że Ukraina jest pęknięta. Nie tylko politycznie, bo każde wybory do swoistego pęknięcia prowadzą. Ukraina jest pęknięta regionalnie. Dzieli się na część zachodnią i wschodnią, jest to dyskusja tych Ukraińców, którzy bardzo troszczą się o swoją kulturową tożsamość, z tymi, którzy czują się zasymilowani ze wschodnim, rosyjskim sąsiadem"”.

7 Cyt. za: „Gazeta Wyborcza” 2004, nr 275, s. 13. Wyraz powierzchownej wiedzy o historii i stosunkach społecznych na Ukrainie dał pochodzący z Hiszpanii przewodniczący Parlamentu Europejskiego Josep Borrell, który na łamach jednej z poczytniejszych polskich gazet stwierdził: „Przez ponad pięć wieków zachodnia część Ukrainy należała do wielkiego królestwa polsko-litewskiego, którego dominacja w tym regionie trwała aż do XVIII wieku, a część wschodnia pozostawała pod wpływem Imperium Rosyjskiego. Po rozbiorach Polski część zachodnią wcielono do imperium austro-węgierskiego, wschodnią zaś oddano we władanie carów. Wyniki ostatnich wyborów znakomicie odzwierciedlają te różnice, tyleż historyczne, co religijne - zachód poparł Juszczenkę, na wschodzie opowiedziano się za Janukowyczem" (J. Borrell, Europa dla Ukrainy, „Gazeta Wyborcza” 2004, nr 296, s. 18). Prócz nieznajomości podstawowych faktów z historii Ukrainy i jej związków z Rzeczypospolitą i Rosją oraz braku wiedzy nt. stosunków wyznaniowych $\mathrm{w}$ tej republice, $\mathrm{w}$ wypowiedzi Borrella razi nielogiczność sądów. Skoro „część wschodnia pozostawała pod wpływem Imperium Rosyjskiego" już przed rozbiorami, jak mogła po rozbiorach być poddana władzy carów? Do połowy XVII w. część wschodnia Ukrainy, podobnie jak zachodnia, wchodziła w skład Rzeczypospolitej. Sytuację geopolityczną zmieniało dopiero powstanie kozackie z 1648 r. Jego skutkiem była tzw. „umowa perejasławska” (1654 r.) między 
Tezę S. Huntingtona, którą umiejętnie posłużyli się ukraińscy i rosyjscy specjaliści od PR i marketingu politycznego, działający na rzecz Janukowycza, falsyfikuje proste porównanie ostatnich wyników wyborów prezydenckich ze strukturą wyznaniową Ukrainy. Otóż, wierni kościoła katolickiego, zarówno obrządku wschodniego (grekokatolicy), jak łacińskiego (rzymskokatolicy), stanowią na Ukrainie społeczność zaledwie piętnastoprocentową. Wyłącznie ich poparcie nie zapewniłoby W. Juszczence, skądinąd deklarującemu przynależność do cerkwi prawosławnej, zdobycia wymaganej bezwzględnej większości. Na tego proeuropejskiego kandydata, zwolennika związania Ukrainy z Europą i strukturami euroatlantyckimi (UE i NATO), zagłosowali w większości nie tylko mieszkańcy zachodniej części kraju (tylko tam cerkiew grekokatolicka jest wyznaniem dominującym), ale również prawosławni obywatele regionów środkowoukraińskich, w tym zwłaszcza Kijowa. To właśnie prawosławni tworzą największą wspólnotę wyznaniową Ukrainy. Większość z nich (ok. 70\%) przynależy do Ukraińskiej Cerkwi Prawosławnej Patriarchatu Moskiewskiego, pozostali zaś do cerkwi, będącej pod jurysdykcją, nie uznawanego przez wspólnotę ortodoksyjna, patriarchy kijowskiego oraz do Ukraińskiej Cerkwi Autokefalicznej. Poza największymi wyznaniami prawosławnymi i katolickimi w obrazie życia religijnego Ukrainy pojawiają się także wyznawcy różnych odłamów protestantyzmu, żydzi oraz muzułmanie $^{8}$.

Juszczenko uzyskał poparcie hierarchii większości wyznań zaznaczających się w życiu społecznym Ukrainy, w tym cerkwi unickiej i kościoła rzymskokatolickiego, obu cerkwi niezależnych od Moskwy (tj. patriarchatu kijowskiego i autokefalicznej), a także duchownych żydowskich i muzułmańskich (np. wielkiego muftiego Krymu). Jedynie silnie

Kozakami a carem rosyjskim, która pod jego panowanie poddawała środkową i wschodnią Ukrainę. Stan ten został potwierdzony na mocy rozejmu polsko-rosyjskiego w Andruszowie w 1667 r. Aczkolwiek jeszcze na początku XVIII w. wybuchło pod wodzą hetmana Iwana Mazepy nieudane powstanie antycarskie na Ukrainie Zadnieprzańskiej, którego celem było zjednoczenie Ukrainy w granicach Rzeczypospolitej. W wyniku rozbiorów Polski rzeczywiście część ziem Ukrainy Prawobrzeżnej przypadła imperium Habsburgów (a nie austro-węgierskiemu, jak pisze Borrell), część zaś (m.in. Podole i część Wołynia) Rosji. Jednak obie te części pod względem geograficznym stanowią dzisiejszą Ukrainę Zachodnią.

${ }^{8}$ Na podstawie: P. Andrusieczko, Sytuacja narodowościowa na Ukrainie po rozpadzie ZSRR (na podstawie prasy polskiej i ukraińskiej), Rozprawa doktorska, UAM Poznań 2003. 
powiązana z Rosją Ukraińska Cerkiew Prawosławna Patriarchatu Moskiewskiego oficjalnie poparła kandydata obozu władzy W. Janukowycza, reprezentującego (zresztą od niedawna) opcję prorosyjską. Nie oznaczało to jednak w praktyce, że wierni tejże wspólnoty wyznaniowej postapili zgodnie ze wskazaniami hierarchii ${ }^{9}$.

Wspólnota prawosławna jest podzielona zarówno co do stosunku do kościoła katolickiego i papiestwa, jak i cywilizacyjnej tożsamości. Konserwatywną, integrystyczną postawę reprezentuje tu przede wszystkim cerkiew rosyjska, która nieprzychylnie odnosi się do inicjatyw ekumenicznych, postrzega Zachód zwykle przez pryzmat jego wad, zaangażowana jest w kształtowanie odrębnej, prawosławnej (bizantyńskiej) tożsamości cywilizacyjnej. Postawę otwartą na ekumeniczny dialog z kościołem katolickim oraz na integrację z cywilizacją zachodnią reprezentują m.in. niezależne od patriarchy moskiewskiego cerkwie ukraińskie, ekumeniczny patriarchat konstantynopolski czy cerkiew rumuńska. Zwierzchnik tej ostatniej, patriarcha Teoktyst (Toader Arapasu, ur. 1915 r.) w następujący sposób scharakteryzował przynależność cywilizacyjną swoich rodaków, w przeważającej mierze wyznawców prawosławia: „nasze chrześcijaństwo zbudowane jest na gruncie kultury łacińskiej, choć jest to wiara prawosławna. Nasza kultura jest bliższa Zachodowi, niż Wschodowi" ${ }^{\prime 10}$. Przez stulecia nośnikiem kultury łacińskiej na wschodniej Słowiańszczyźnie była właśnie cerkiew ukraińska, która zachowała odrębność i niezależność do 1686 r., kiedy to podporządkowana została patriarchatowi moskiewskiemu. Duży udział w procesie latynizacji cerkwi prawosławnej miał pochodzący z Mołdawii metropolita kijowski Piotr Mohyła, założyciel prawosławnej uczelni teologicznej, która co prawda miała bronić prawosławia przed „unią brzeską”, ale za pomocą metod wypracowanych w obszarze kultury łacińskiej. Latynizacja cerkwi prawosławnej na Ukrainie, a za jej sprawą także w Rosji, objęła zarówno język, jak i teologię, obyczaje oraz świadomość religijną ${ }^{11}$.

Przeciwko zasadności uznania podziału cywilizacyjnego Ukrainy według kryterium wyznaniowego przemawia też fakt, że czynniki dezintegracyjne ujawniły się na obszarze (Charków, Donieck, Ługańsk), gdzie przeważa ludność deklarująca bezwyznaniowość albo ateizm; zaledwie

9 B. Osadczuk, O krok od tragedii, „Forum” 2005, nr 4, s. 19.

10 Któż nie klaskał władzy. Rozmowa Bogumiła Lufta z Teoktysem, patriarcha Rumuńskiego Kościoła Prawosławnego, „Rzeczpospolita” 07.11.2000.

11 Zob. A. Walicki, Rosja, katolicyzm i sprawa polska, Warszawa 2002, s. 22 i n. 
28\% ogółu mieszkańców wschodniej Ukrainy deklaruje przynależność do jakiegokolwiek kościoła czy związku wyznaniowego ${ }^{12}$.

Oznacza to, że głównym czynnikiem podziałów społecznych i politycznych na Ukrainie nie jest wcale przynależność wyznaniowa. Należy przede wszystkim zwrócić uwagę na poziom rozwoju gospodarczo-społecznego, który w nie mniejszym stopniu niż przynależność wyznaniowa determinuje system wartości, obyczaje, postawy i świadomość polityczną zbiorowości, etc. Brytyjski socjolog, niemieckiego pochodzenia, Ralf Dahrendorf stwierdza, że zmianom w strukturze zatrudnienia towarzyszą zmiany w sferze wartości ${ }^{13}$. Obecnie świat przechodzi od gospodarki industrialnej do postindustrialnej, czyli od „towarów” do „usług”, przy czym w dalszym ciagu zachowane są obszary i enklawy, w których dominuje ład przemysłowy, a nawet agrarny. Według cenionego amerykańskiego futurologa Alvina Tofflera główny światowy konflikt rozgrywać się będzie między ładem industrialnym a światem postindustrialnym, tak jak w przeszłości między agraryzmem a industrializmem. Nie będzie jednak jasno wytyczonych granic odpowiadających podziałowi na poszczególne państwa narodowe $i$ ich sojusze, cywilizacje partykularne czy obozy ideologiczne państw, nie będzie to też konflikt między Północą i Południem. Ujawniać się on będzie tam, gdzie nachodzą na siebie, stosując terminologię Tofflerowską, tzw. fale cywilizacyjne ${ }^{14}$. Będzie to zatem zarówno konflikt globalny, gdy weźmie się pod uwagę cały świat, który przecinany jest przez kolejne fale cywilizacyjne, jak i lokalny, gdy analizie podda się dzisiejsze państwa, zwłaszcza te, w których dominacja jednego z ładów społeczno-ekonomicznych (w szczególności postindustrialnego) nie jest znacząca, co odnosi się m.in. do państw znajdujących się w fazie transformacji ustrojowej, gdzie system realnego socjalizmu zakonserwował tradycje i instytucje gospodarcze społeczeństwa przemysłowego, a nawet, co wydać się może paradoksem, ładu agrarnego, o czym świadczy chociażby struktura zatrudnienia w krajach środkowo i wschodnioeuropejskich, w których pracujący w rolnictwie stanowią znaczny odsetek ludności.

Pod względem gospodarczym Ukraina jako całość jest krajem rozwijającym się, co potwierdzają statystyki. W 2002 r. produkt krajowy brutto

12 Za: A. Wilson, op. cit., s. 251.

13 Zob. R. Dahrendorf, Nowoczesny konflikt spoleczny. Esej o polityce wolności, Warszawa 1993, s. 215.

14 A. i H. Toffler, Budowa nowej cywilizacji. Polityka trzeciej fali, Poznań 1996, s. $17-36$. 
per capita wynosił zaledwie 770 dolarów (w oficjalnych statystykach nie ujmuje się tzw. ,szarej strefy”) i był przykładowo pięciokrotnie niższy niż w Polsce. W strukturze zatrudnienia i źródeł PKB dominuje sektor usług. Zatrudnionych jest w nim ok. 56\% Ukraińców, wytwarza on $49 \%$ PKB. W przemyśle znajduje zatrudnienie ok. $30 \%$ obywateli republiki, generuje on $38 \%$ PKB. Nadal poważnym sektorem gospodarki ukraińskiej jest rolnictwo, gdzie pracuje 22\% Ukraińców i które jest źródłem 13\% PKB. Pod koniec lat $90.12 \%$ dorosłych Ukraińców pozostawało bez pracy ${ }^{15}$. W rozwoju gospodarczym Ukrainy dają się zauważyć silne zróżnicowania regionalne. Rolnictwo skoncentrowane jest głównie na zachodzie i w centrum kraju, podczas gdy przemysł na wschodzie (głównie obwody: doniecki, ługański, dniepropietrowski, zaporoski), skąd wywodzą się najsilniejsze zarówno pod względem posiadanych zasobów finansowych, jak i wpływów w sferze politycznej grupy oligarchów. Natomiast stolica republiki Kijów stanowi nie tylko centrum życia państwowego, ale także główny ośrodek gospodarki postindustrialnej, wyraźnie odznaczający się na tle reszty kraju tak pod względem bogactwa, jak poziomu rozwoju cywilizacyjnego; jest dynamicznie rozwijającym się centrum naukowym, kulturalnym, oświatowymi i finansowym (banki i inne instytucje finansowe) ${ }^{16}$.

Kandydata reprezentującego opcję prorosyjską poparł zasadniczo pozostający w ładzie industrialnym Wschód kraju; tam też pojawiły się sprowokowane przez władze dążenia separatystyczne. Nie było to bynajmniej związane tylko z dominacją języka rosyjskiego oraz ludności pochodzenia rosyjskiego na tym obszarze. W przeważającej mierze rosyjskojęzyczna jest też przecież stolica Ukrainy, w której wszakże największe poparcie zdobył kandydat proeuropejski. Generalnie Wschód Ukrainy jest swoistym reliktem radzieckim (industrialnym również, gdy ZSRR był próbą urzeczywistnienia ideologii industrializmu); tam przetrwała postawa, którą określa się mianem homo sovieticus. Mieszkańcy wschodniej części republiki są przywiązani do spuścizny radzieckiej, dlatego ujawniają się tam często postawy prorosyjskie, gdyż to właśnie w integracji z Rosją i innymi państwami postradzieckimi upatruje się możliwości wskrzeszenia swego rodzaju ,Związku Radzieckiego - bis”. Miejsce dygnitarzy partyjnych zajęli na Wschodzie tzw. oligarchowie oraz powiązani z nimi ludzie władzy (gubernatorzy regionów, merowie miast, a także decydenci polityczni

15 Świat w liczbach 2002, Warszawa 2003, s. 214.

16 F. Zastawnyj i W. Kusiński, Ukraina. Przyroda-ludność - gospodarka, Warszawa 2003, s. 249-278. 
z Kijowa). Oni skupili w swoich rękach nie tylko ogromny kapitał finansowy, ale również faktyczną władzę. Ich pozycję ugruntował brak pluralizmu medialnego. Wolne media działały jedynie na zachodzie i w centrum Ukrainy. Wschodnia, a także południowa część republiki była poddawana silnej propagandzie obozu władzy. Propaganda ta padła na podatny grunt, jej odbiorcą stał się „człowiek radziecki”. Tak Donbas, największy pod względem liczby mieszkańców obszar wschodniej Ukrainy, skąd wywodzi się W. Janukowycz i gdzie uzyskał on największe poparcie, charakteryzuje ukraiński publicysta Mykoła Riabczuk: ,zamieszkują [Donbas A.M.] ludzie radzieccy. To klasyczny obszar postkolonialny, który nigdy nie istniał poza zasięgiem Imperium Rosyjskiego. To region okropnej sowieckiej industrializacji. Jego mieszkańcy mają poczucie, że są ważni: w ZSRR zapewniano ich, że klasa robotnicza jest najważniejsza, teraz im się wmawia, że karmią Ukrainę. W Donbasie system autorytarny nie tylko nie osłabł, ale się wzmocnił. Powstało coś w rodzaju państwa w państwie, gdzie doszło do scalenia mafii i władzy" ${ }^{\prime 7}$.

Analizując tożsamość ukraińską Olga Hnatiuk zwróciła uwagę na trzy orientacje kulturowe współczesnych Ukraińców:

1) proeuropejską (prozachodnią);

2) prowschodnia,

3) pronarodową.

Zwolennicy pierwszych dwu orientacji szukają wzorców kultury ukraińskiej „na zewnątrz” bądź to w cywilizacji europejskiej (pierwsza opcja), bądź we wspólnocie wschodniosłowiańskiej czy też, sięgając głębiej, w prawosławiu, nierzadko podkreślając przy tym dziedzictwo radzieckie Ukrainy (druga opcja), podczas gdy „narodowcy” wzorców doszukują się „wewnątrz” kultury ukraińskiej, niekiedy prezentując postawy autarkiczne, uznając „obce” wpływy za szkodliwe ${ }^{18}$.

Relacje między poszczególnymi orientacjami przedstawić można w postaci łańcucha trzech kół. Dwa skrajne miejsca zajmują w tym łańcuchu, wykluczające się tożsamość europejska i wschodnia (radziecka, wschodniosłowiańska). Tożsamość ukraińska może natomiast stanowić zarówno wartość autoteliczną, jak być uzupełnieniem bądź tożsamości

17 Naród i jego rewolucje. Z Mykoła Ribaczukiem rozmawia Andrzej Brzeziecki, „Tygodnik Powszechny” 2005, nr 3, s. 13.

${ }_{18}$ O. Hnatiuk, Pożegnanie z imperium. Ukraińskie dyskusje o tożsamości, Lublin 2003, s. 57. 
europejskiej, bądź wschodniej (radzieckiej) ${ }^{19}$. Relacje te przedstawiono na poniższym modelu graficznym.

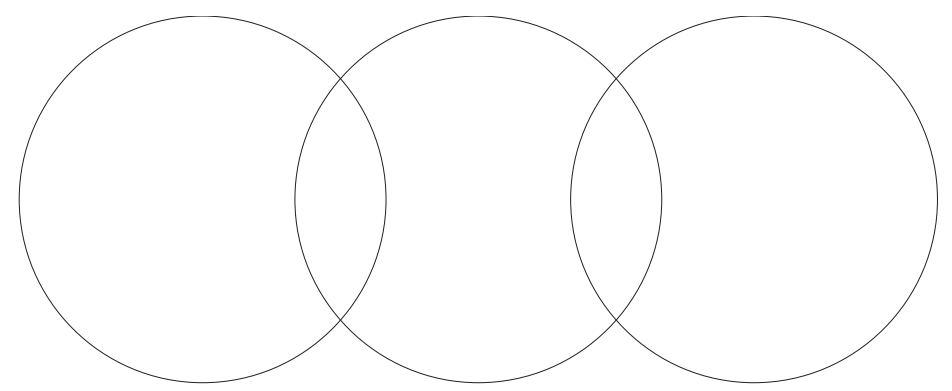

Tożsamość europejska - tożsamość ukraińska - tożsamość (post)radziecka

Źródło: O. Hnatiuk, op. cit., s. 46.

Intensyfikacja występowania poszczególnych orientacji kulturowych wśród społeczeństwa ukraińskiego zależy od regionu. Zachodnia Ukraina przywiązana jest zarówno do kultury narodowej, jak i europejskiej. Rzadziej występuje tam opcja postradziecka czy wschodniosłowiańska. Kijów jako centrum przeobrażeń postindustrialnych zorientowany jest bardziej na cywilizację zachodnią utożsamianą z postępem, wartościami demokratycznymi, wysokim standardem życia, etc., mimo że mieszkańcy stolicy używają na co dzień języka rosyjskiego. Wschód i w mniejszym stopniu Południe Ukrainy to obszar postradziecki i filorosyjski, stąd też częściej niż gdzie indziej pojawia się tam orientacja prowschodnia, która wszakże nie oznacza wcale większego przywiązania do religii prawosławnej, ale raczej do spuścizny radzieckiej.

Mimo współwystępowania na Ukrainie trzech, często przeciwstawnych, rodzajów tożsamości i identyfikacji kulturowej i cywilizacyjnej, widmo rozpadu ukraińskiego państwa jest raczej w sferze political fiction niż realpolitik. Jak trafnie zauważa brytyjski ukrainista Andrew Wilson: „różnice między najbardziej na zachód wysuniętymi połaciami Galicji a Donbasem i Krymem narastają, czy też (jeśli kto woli) maleją stopniowo i płynnie - nie ma więc mowy o jakiejś precyzyjnie wyznaczonej linii, wzdłuż której kraj mógłby pewnego pięknego dnia pęknąć na dwoje"20.

19 Ibidem, s. 46.

20 A. Wilson, op. cit., s. 219. 


\section{Orientacja cywilizacyjna „pomarańczowej rewolucji”}

Strategia polityki zagranicznej władz ukraińskich przed „pomarańczową rewolucją" nie była jednoznaczna. $Z$ jednej strony wyrażano wolę integracji z Zachodem; deklarowano chęć akcesji zarówno do Unii Europejskiej, jak i Paktu Północnoatlantyckiego. Przykładem okcydentalizacji polityki zagranicznej było wysłanie wojsk ukraińskich do Iraku, gdzie stanowiły one część międzynarodowego kontyngentu pod dowództwem Polaków. Z drugiej strony podejmowano inicjatywy integracyjne w ramach współpracy z państwami postradzieckimi, szczególnie zaś z Federacją Rosyjską. Orientacja wschodnia w polityce zagranicznej Ukrainy stała się dominująca pod koniec drugiej kadencji prezydenta Leonida Kuczmy, co wiązało się raczej z chłodną kalkulacją wyborczą ekipy rządzącej, dążącej do zachowania status quo w relacjach wewnątrzukraińskich, niż z zasadniczym i trwałym przeorientowaniem polityki zagranicznej. Zarówno L. Kuczma, jak i grupa powiązanych z nim polityków i biznesmenów była coraz gorzej postrzegana przez zachodnią opinię. Zarzucano im podatność na korupcję i nepotyzm oraz tendencje autorytarne, a nawet oskarżano o czyny kryminalne, m.in. o zlecanie zabójstw opozycyjnych dziennikarzy, w tym najgłośniejsze Georgija Gongadzego ${ }^{21}$. Dlatego zachodni politycy odwrócili się od Kuczmy i wytypowanego na jego następcę Janukowycza. Jedynym zatem zagranicznym sojusznikiem obozu władzy na Ukrainie, który mógłby zasadniczo wpłynąć na wynik wyborów, był prezydent Federacji Rosyjskiej Władymir Putin. Poparcie, a zarazem wsparcie (m.in. udział związanych z władzami rosyjskimi specjalistów od marketingu politycznego w kampanii wyborczej po stronie Janukowycza), którego udzielił Kreml Janukowyczowi, okupione zostało zbliżeniem się Ukrainy do Rosji oraz zmianą kursu w jej polityce zagranicznej. Priorytetem stała się integracja, tym razem jednak nie z Unią Europejską i NATO, ale z państwami postradzieckimi.

Natomiast opozycja skupiona wokół Juszczenki była generalnie proeuropejska. Nawet popierający go nacjonaliści, którzy wcześniej akcentowali neutralność i konieczność samodzielnego rozwoju Ukrainy jako gwarancji jej pełnej suwerenności i integralności, opowiedzieli się zasadniczo za orientacją europejską w polityce zagranicznej. W tzw. „obozie opozycji” nie ujawniały się tendencje prorosyjskie. Juszczenka był po-

21 Zob. P. Cywiński, R. Boyes, Koniec Europy, Warszawa 2004, s. 94-96. 
strzegany przez Zachód jako polityk umiarkowany, demokrata, zwolennik wolnego rynku; nie ciążyło na nim, mimo że był prezesem banku narodowego i premierem, odium polityka skorumpowanego i uwikłanego w quasi-mafijne interesy. Dlatego mógł on liczyć na poparcie zachodnich mediów i polityków, aczkolwiek ci ostatni udzielali mu go nie zawsze wprost, przynajmniej do czasu ogłoszenia wyników drugiej tury, kiedy było już pewne, że została ona sfałszowana przez zwolenników ancien régime.

Zdecydowanie prozachodnia postawa W. Juszczenki wyrażała się m.in. w jasnej deklaracji podjęcia niezbędnych wysiłków na rzecz integracji Ukrainy ze strukturami euroatlantyckimi, w tym szczególnie z Unią Europejska, jak również wyznaczeniu Ukraińcom miejsca wśród narodów europejskich oraz podkreślaniu kulturowych i aksjologicznych więzi społeczeństwa ukraińskiego z Europą. Również w osobistych enuncjacjach Juszczenko określał się jako Europejczyk. W jednym z wywiadów niedługo po tym, jak ogłoszono jego zwycięstwo w wyborach stwierdził: ,jeżeli chodzi o kierunek, w jakim zmierza Ukraina, to nie muszę i nie chcę nikomu udowadniać, że ten kraj zawsze należał do środkowej Europy, a ja jestem Europejczykiem. Zarówno mój naród, jak i ja pod każdym względem jesteśmy europejscy, nasze wartości, aspiracje, światopogląd wypływają z europejskiej tradycji. Dlatego strategią mojego rządu będzie integracja europejska"22. Obecnie podobnie ukierunkowana jest większość ukraińskiego społeczeństwa. W lutym 2005 r., a więc na krótko po „pomarańczowej rewolucji”, przeprowadzono ogólnoukraińskie badnia socjologiczne, z których wynika, że 44\% ogółu obywateli Ukrainy opowiada się za integracją z Europą. Przeciwnego zdania jest 28\% Ukraińców. Także $28 \%$ respondentów na pytanie o integrację ze strukturami europejskimi udzieliło odpowiedzi „,nie wiem” ${ }^{\text {23 }}$. Duży odsetek przeciwników i niezdecydowanych co do przyszłości Ukrainy w strefie euroatlantyckiej potwierdza tezy o pęknięciu społeczeństwa ukraińskiego, jednakowoż nie oznacza to wcale dychotomicznego podziału cywilizacyjnego na europejski Zachód i prawosławny Wschód. W grupie 44\% zwolenników opcji europejskiej są zarówno uniccy mieszkańcy zachodniej części kraju, jak i prawosławni z środkowej Ukrainy, a i zapewne mieszkańcy regionów wschodnich i południowych. W dużej mierze poparcie dla idei integracji

22 Przebudzenie Ukrainy. Rozmowa z Wiktorem Juszczenka, prezydentem elektem Ukrainy, „Wprost” 2005, nr 1, s. 22-23.

23 Za: TVP, Pr. 1., „Wiadomości” z 24 lutego 2005, godz. 19.30. 
z Europą wynikać będzie z poparcia, jakie aktualnie mieć będą nowo wybrane władze republiki, w tym szczególnie prezydent Juszczenko.

Nie bez znaczenia w tym względzie będzie też postawa państw członkowskich Unii Europejskiej i NATO. Jeśli jasno wyrażą wolę przyjęcia Ukrainy do swoich struktur, precyzując m.in. warunki członkostwa i datę wstąpienia, można przypuszczać, że zostanie to przez społeczeństwo ukraińskie dobrze przyjęte; realna perspektywa integracji ze strukturami zachodnimi przyczyni się do zwiększenia nastrojów proeuropejskich wśród Ukraińców. Wypowiedzi polityków europejskich nie są jednak jednoznaczne, co w przyszłości może z kolei wpłynąć negatywnie na postawy mieszkańców Ukrainy względem integracji z Zachodem. Wystąpi wówczas zjawisko zmęczenia wyczekiwaniem na zaproszenie do struktur euroatlantyckich, a następnie narastać będzie frustracja i irytacja społeczna, w której efekcie dojść może do kolejnej reorientacji cywilizacyjnej. Naturalną przestrzenią, do której ciążyłaby wtedy Ukraina jest Rosja i kraje z nią integrujące się bądź już zintegrowane. Narastać mogłyby też postawy nacjonalistyczne oraz towarzyszące im dążenia do stworzenia państwa samowystarczalnego (autarkicznego), neutralnego w stosunkach z dwoma obozami integracyjnymi, tzn. europejskim i postradzieckim. Aktywną politykę na rzecz integracji Ukrainy ze strukturami organizacyjnymi świata zachodniego, w tym zwłaszcza z Unią Europejską, prowadzą jak na razie politycy z nowych państw członkowskich. Zauważa się tu zaangażowanie m.in. prezydenta Polski Aleksandra Kwaśniewskiego. Natomiast dużą sympatią darzą Ukraińców społeczeństwa europejskie. W badaniu opinii publicznej sześciu największych państw nowej Unii Europejskiej, tj. Niemiec, Wielkiej Brytanii, Francji, Włoch, Hiszpanii i Polski za przyjęciem Ukrainy do struktur unijnych opowiedziało się aż 77\% Polaków, 62\% Włochów, 60\% Hiszpanów, 58\% Francuzów oraz 49\% Brytyjczyków i $41 \%$ Niemców ${ }^{24}$. Tak duże poparcie jest w dużej mierze wynikiem kampanii medialnej, w której pozytywnie przedstawiano „pomarańczową rewolucję" jako walkę o wartości liberalne i demokratyczne. Tym niemniej taki stosunek Europejczyków z największych krajów Unii daje Ukraińcom poczucie więzi i przynależności, potwierdza w nich przekonanie, że

24 Za: „Gazeta Wyborcza” 2005, nr 70, s. 1 i 10. Ci respondenci, którzy opowiedzieli się za wejściem Ukrainy do UE najczęściej jako główny argument podawali fakt, że jest ona częścią Europy oraz że członkostwo w Unii wzmocni na Ukrainie demokrację. Sporo zwolenników przyjęcia Ukrainy do UE podkreślało też korzyści ekonomiczne, tj. intensyfikację wymiany gospodarczej. 
są członkami europejskiej rodziny narodów, i że w zjednoczonej Europie jest ich miejsce. Jest także sygnałem dla decydentów, że opinia publiczna życzy sobie przyjęcia Ukrainy do UE. Nastroje te nie są raczej trwałą tendencją. Będą maleć wraz z malejącym zainteresowaniem mediów sprawami ukraińskimi oraz wraz z pojawianiem się pytań o koszty rozszerzenia. Dlatego, jeśli politycy zachodni widzą szansę na integrację z Ukrainą, powinni już na tym etapie dołożyć wszelkich starań, by zacząć przygotowania do poszerzenia Unii o ten kraj.

\section{„Efekt lawiny"}

Ukraińska ,pomarańczowa rewolucja” jest drugim tego typu wydarzeniem politycznym na obszarze byłego Związku Radzieckiego, w wyniku którego udało się demokratycznej i proeuropejskej opozycji przejąć władzę. Pierwszą była tzw. „rewolucja róż” (nazwa wzięła się od róż niesionych przez demonstrantów, domagających się zmiany władzy) w Gruzji (2003 r.), podczas której odsunięto od władzy prezydenta Edwarda Szewardnadzego oskarżanego o sfałszowanie wyborów parlamentarnych. Nowo wybrany prezydent Gruzji Micheil Saakaszwili, podobnie jak W. Juszczenko, demonstruje przywiązanie do wartości i symboli cywilizacji europejskiej. Np. w jego gabinecie obok flagi narodowej zawieszona jest flaga Unii Europejskiej. Dokonał on też zmiany kursu gruzińskiej polityki zagranicznej; głównym jej priorytetem stało się ograniczenie wpływów rosyjskich w tej południowokałkaskiej republice, co nie udało się jego poprzednikowi (Rosjanie kontrolują sytuację w dwóch regionach, które faktycznie oderwały się od Gruzji i ogłosiły niepodległość, tj. w Abchazji i Osetii Południowej; obie republiki nie są uznawane przez wspólnotę międzynarodową) oraz integracja ze strukturami euroatlantyckimi ${ }^{25}$.

25 Niekiedy za pierwowzór obu „rewolucji” podaje się w doniesieniach medialnych serbską ,drogę do demokracji” i odsunięcie od władz ekipy byłego prezydenta Slobodana Milosevica (2000 r.). We wszystkich trzech krajach zauważalny był aktywny udział organizacji młodzieżowych (w Serbii - „Otpor”, w Gruzji - „, Kmara” i na Ukrainie - „Pora!”) oraz polityków młodszej generacji. Również w przypadku Serbii, chodziło o zmianę orientacji cywilizacyjnej. Demokraci, którzy przejęli władzę raczej wiążą nadzieje z integracją europejską niż z zacieśnianiem współpracy z Rosją. Władzom rosyjskim zależało na utrzymaniu status quo w relacjach wewnątrzserbskich, co dawało im gwarancje zachowania wpływów politycznych i ekonomicznych na obszarze Bałkanów. 
Czy wydarzenia w tych dwóch postradzieckich republikach zwiastują powszechną na terenie byłego ZSRR tendencję zmian władzy oraz reorientacji w polityce zagranicznej? W wyjaśnianiu zjawisk politycznych, które pojawiają się w różnych krajach w bliskich odstępach czasu, politolodzy posługują się niekiedy kategorią tzw. „efektu lawiny”. Tak tłumaczy go przywoływany już amerykański politolog S. Huntington: „Ważną przyczyną wystąpienia $x[$ [,x” jest symbolem określonego zjawiska politycznego - A.M.] w jednym kraju może być fakt, że $x$ wystąpiło w innym kraju. Gdyby $x$ miałyby miejsce absolutnie jednocześnie, nie byłoby możliwe. Wydarzenia bardzo rzadko następują dokładnie w tym samym momencie, a możliwość występowania identycznych wydarzeń równocześnie, lecz w izolacji od siebie, staje się rzeczywiście coraz mniej prawdopodobna. Wiedza o ważnych wydarzeniach politycznych przekazywana jest prawie natychmiast całemu światu. W związku $\mathrm{z}$ tym wydarzenie $x$ w jednym kraju jest w stanie równocześnie spowodować podobne wydarzenia w innym kraju"26.

Ostatnio w byłych republikach radzieckich doszło do kilku wydarzeń świadczących o zadziałaniu „efektu lawiny”. Takie wydarzenia, nie zawsze związane z wyborami, ale będące formą kontestacji władzy i/lub prób przeorientowania polityki zagranicznej, wystapiły na krótko po ukraińskiej „pomarańczowej rewolucji” na Białorusi, w Mołdawii i w Kirgizji. Podobne tendencje ujawniają się też w Federacji Rosyjskiej, gdzie doszło do monopolizacji i centralizacji władzy przez środowisko prezydenckie. Młodzież rosyjska na wzór ukraińskich kolegów utworzyła organizację „Pora!”, popierającą demokratycznego i liberalnego polityka, byłego premiera FR, Michaiła Kasjanowa. Kolejną byłą republiką radziecką, w której mogą pojawić się antyrządowe wystąpienia, jest Azerbejdżan, gdzie studenci stołecznej politechniki i uniwersytetu powołali do życia organizację o wymownej nazwie: Pomarańczowy Ruch Azerbejdżanu ${ }^{27}$. Powstanie tego typu organizacji i oddolnych ruchów społecznych nie jest jeszcze miarą sukcesu. To, czy w innych krajach Wspólnoty Niepodległych Państw powtórzy się scenariusz gruziński i ukraiński, zależy od wielu czynników, m.in. poparcia społecznego, pozycji władz w służbach bezpieczeństwa $\mathrm{i}$ armii, zaangażowania $\mathrm{w}$ sprawy wewnętrzne sił zewnętrznych. Tym niemniej zjawiska te uzmysławiają, że są w krajach tych

26 S. P. Huntington, Trzecia fala demokratyzacji, Warszawa 1995, s. 42-43.

27 „Nowa Europa Wschodnia” 2005, nr 1, Dodatek „Tygodnika Powszechnego” 2005, nr 16, s. 25-28. 
ludzie, którzy nie godzą się z autorytarną polityką władz oraz dążą do demokratyzacji i liberalizacji stosunków wewnątrzpaństwowych. W niektórych przypadkach (Białoruś, Rosja, Mołdawia) podkreślają też przywiązanie do wartości cywilizacji europejskiej i wyrażają wolę zaangażowania się $\mathrm{w}$ proces integracji $\mathrm{w}$ ramach struktur euroatlantyckich.

Najbardziej jaskrawym przykładem siły oddziaływania ukraińskiej „pomarańczowej rewolucji” jest Mołdawia, gdzie podczas ostatnich wyborów parlamentarnych kolorem pomarańczowym posłużyli się opozycyjni wobec rządzących komunistów (Partia Komunistów) chrześcijańscy-demokraci (Ludowa Partia Chrześcijańsko-Demokratyczna), którym nieoficjalnego poparcia udzielił zresztą sam Juszczenko. Jednak zarówno opozycja, jak rządzący manifestują przywiązanie do kursu europejskiego oraz domagają się ograniczenia ingerencji władz Federacji Rosyjskiej w wewnętrzne sprawy Mołdawii ${ }^{28}$. Aczkolwiek jeszcze w 2001 r. komuniści występowali w kampanii wyborczej jako siły prorosyjskie, domagali się m.in. integracji Mołdawii ze Związkiem Białorusi i Rosji. Na zmianę kursu wpływ miała nieugięta postawa Rosji wobec Naddniestrza. Będący u władzy komuniści zaczęli wówczas szukać sojuszników na Zachodzie ${ }^{29}$. Wygrana Juszczenki w sąsiadującej z Mołdawią Ukrainie wpłynęła nie tyle na zmianę władzy na mołdawskiej scenie politycznej (komuniści wygrali wybory, uzyskując poparcie ok. $42 \%$ wyborców $^{30}$ ), ale na wzmocnienie polityki proeuropejskiej. Z geopolitycznej perspektywy - Mołdawia jest położona między aspirującą obecnie do członkostwa w UE Ukrainą a Rumunią, która stanie się członkiem Unii prawdopodobnie w 2007 r. - kraj ten staje się w coraz większym stopniu europejski.

28 Napięcie w stosunkach między oboma państwami wywołuje nieuznana przez wspólnotę międzynarodową tzw. Republika Naddnieprzańska, gdzie przeważają Rosjanie, którzy wystąpili przeciwko niepodległości Mołdawii i jej ewentualnemu zjednoczeniu z sąsiednią Rumunią (Mołdawianie posługują się językiem rumuńskim i wyróżniają się na ogół podwójną identyfikacją narodową: rumuńsko-mołdawską). Gwarancją wewnętrznej suwerenności Rep. Naddniestrzańskiej są stacjonujące wojska rosyjskie, które oficjalnie funkcjonują tam jako siły stabilizacyjne. Ich obecność jest uznawana przez władze mołdawskie jako mieszanie się Rosji w wewnętrzne sprawy Mołdawii. Zob. A. Kosińska, Konflikt naddniestrzański, (w:) Stosunki międzynarodowe: Historia. Regiony. Polityka, pod. red. P. Czachorowskiego i R. Ożarowskiego, Gdańsk-Warszawa 2004, s. 203-209.

29 R. Pankowski, Rewolucja już była, ,Gazeta Wyborcza” 2005, nr 52, s. 25-26.

30 Za: http://serwisy.gazeta.pl/swiat/1,34272,2587915.html. 


\section{Summary}

The paper attempts to explain in civilizational terms the 'orange revolution' that has transformed Ukrainian internal and foreign policy. It is also a dispute with the standpoint of the American political scientist, Samuel P. Huntington, and many Western politicians who oversimplify the civilizational situation of Ukraine. They assume that Ukraine is divided in terms of civilization and that the main criterion for this division is related to religious denomination. Believers of the Catholic Church are thus supposed to determine the scope of European civilization whereas those of the Orthodox Church determine Byzantine civilization. This theory was falsified during the latest elections when both Catholics and Orthodox Christians from three communities in Ukraine voted for Viktor Yushchenko, a representative of a pro-European option. The noticeable division of the country seems to be a consequence of different levels of civilizational development rather than that of denomination. The pro-Russian option, represented by Viktor Yanukovych, emerged strongly in the industrial east of Ukraine, where nostalgia for the Soviet Union is the strongest and post-Soviet identity is a predominating paradigm of group identity. The agricultural west, free from the Soviet 'modernization', and post-industrial Kiev chose the European direction as they voted for the pro-European candidate, Yushchenko. The success of the 'orange revolution' and Yushchenko's victory in the third round significantly changed the geopolitical situation in Eastern Europe and in the former Soviet Union. The position of Russia in this region was somewhat weakened. It has also raised hopes for the democratization of such countries as Byelorussia or the Russian Federation, at present witnessing the rejection of principles and values of liberal democracy. 